\section{ON SOME REMARKABLE CFANGES PRO. DUCED IN IRON AND STEEL BY THE ACTION OF HYDROGEN AND ACIDS}

$\mathrm{FOR}$ a long time it has been well known to wiredrawers and other manufacturers, who free the iron or steel they are engaged in working from rust by cleaning it with sulphuric acid, that after this process the metal becomes much more brittle than before. Further, if a piece of iron wire that has been cleaned in sulphuric acid be bent rapidily to and fro till it is broken, and the fracture be then moistened with the tongue, bubbles of gas arise from it, causing it to froth. If this same wire be now gently heated for a few hours, or left in a dry warm room for some days, it will be found to have regained its original toughiness, and not to froth when broken and the fracture moistened.

Some experiments made by the writer on this subject during the last three years, have shown that not only sulphuric, but hydrochloric, acetic, and other acids which give off hydrogen by their action on iron, produce the same effect, making it probable that hydrogen is the cause of the change. This view is confirmed by collecting the gas given off at the surface of the iron and burning it, when the characteristic flame of hydrosen is seen.

Putting the facts together, it seems probable that a portion of the hydrogen generated by the action of the acid on the surface of the iron is occluded and subsequently given off, either rapidly, as when the iron is heated by the effort of breaking it causing the water on the surface of fracture to bubble, or, more slowly, in the cold.

Perhaps the simplest way of charging a piece of iron with hydrogen is by laying it on a sheet of zinc in a basin of dilute sulphuric acid. An electric current is here set up, and the hydrogen generated by the action of the acid on the zinc is given off at the surface of the iron. In this way two minutes or even less will often suffice to charge a piece of iron with hydrogen and alter its properties as completely as one hour's immersion in dilute acid without the zinc.

The change in the properties of iron which has occluded hydrogen is not confined to a diminution of toughness, though this may be reduced to one-fourth, but is accompanied by a remarkable decrease in tensile strain, amounting in cast steel to upwards of twenty per cent. after twelve hours' immersion in sulphuric acid. With iron wire the decrease in tensile strain was found to be less than with steel; the reduction amounted however in some cases to six per cent. Some interesting differences are noticeable in the relative effect of occluded hydrogen on mild steel and highly carbonised steel, the diminution of tensile strain after occlusion of hydrogen being greater in the latter case than in the former.

$\Lambda$ s with the metal paladium, so with iron, the electrical resistance is increased somewhat by occlusion of hydrogen ; in fact, it seems probable that every property of iron or steel undergoes a change after the occlusion of hydrogen, and the extent of this change becomes a matter of great interest to the engineer now that iron and steel are so largely used.

Cases of the deterioration in toughness of iron of excellent quality exposed to the action of gas containing acid, as in the upcast shaft of a coal-pit, have come before the as in the upcast shaft of a che resulted more from hydrogen occluded by the iron than resulted more from hydrogen occluded it is also probable its corrosion by the acid vapours. It is also probable weakened in strength and toughness.

$$
\text { WILliaM H. JOHNSON }
$$

\section{THE SOUTHPORT AQUARIUM}

$T$ HE grounds of the Southport Pavilion, Winter Gardens, 1 and Aquarium Company occupy an area of about nine acres, extending from a portion of the sea-wall and parade, on which they have a frontage of $\mathrm{I}, \mathrm{I} I \mathrm{O}$ feet, to Lord Street, the chief thoroughfare of the town, which runs in a straight line, roughly parallel to the sea-coast, for nearly a mile.

Entering the pile of buildings, which occupy about the centre of the grounds, by the chief portico on the Lord Street side, and ascending a wide flight of steps, the Promenade $\mathrm{Hall}$ is reached, which is constructed of pitch pine, and is over the principal corridor of the aquarium, to which access is obtained by descending a flight of steps, or an incline, placed on either side of the staircase leading up to the hall, which, like the corridor beneath it, is 160 feet in length by 42 . To the right of the hall, and separated from it by glass doors, is the Band Pavilion, which is said to be capable of holding 2,000 people; round it is a gallery used as a promenade, and in which pictures are exhibited, and beneath it is the refreshment department, which is on the basement level. Like the aquarium, * the Pavilion is oval in shape, the longest axis being 136 feet, the shortest 76 . To the left of the great hall, glass doors give admittance to a glass conservatory, 174 feet in length by 74 , stocked with tropical and subtropical plants and birds; beneath it are the remaining corridors of the aquarium.

The first corridor of the aquarium contains twenty-three tanks, the front of each consisting of three sheets of plate glass, as at Brighton ; and the light, as there, is all transmitted either through the water in the tanks or through plates of opaque glass placed in the floor above. The roof consists of double groined arches, supported on moulded columns, made of concrete, which has been largely used in various parts of the building with good results.

Tanks 1 to 23 contain: Sea Anemones, Nos. 7 and 23; Octopi, II and $2 \mathrm{I}$; Crabs, Spiny and Common Lobsters, I0, 16, I9, and 22 ; four specimens of King Crabs, 20 ; Conger and Common Eels; Salmon Trout; Ballan Wrasse, 6; Rough Hound and other dog-fish ; Cod and Rock Cod; Grey, Streaked, and other Gurnards; Whiting, Soles, Plaice, Bret, \&c. ; Father Lasher (Cottus scorpeus), 4 ; two specimens of the Angel or Monk Fish, 15.

By the side of the tanks, plates of fishes from Yarrel's work are hung, which, not always having any connection with the living fish exhibited, rather distract attention, and would be better collected together with various stuffed fish placed at the top of the tanks, and placed in a small museum. Amongst the plates are some original coloured drawings of $\mathrm{Mr}$. Jonathan Couch, of seven species of sharks, signed "J. C., I 825 "; also eight drawings of flying-fish, by the same.

Corridor No. 2 has a flat ceiling supported on iron columns, is lighted by windows looking on to the garden on the Lord Street side, and contains table tanks, rectangular and octagonal, the former being filled with fresh water, the latter with salt, containing, amongst other things, several species of Serpula, Sabella, Terebella, Amphritite, Aphrodita aculeata, and other annelides Sea Anemones of various species; Thyone papillosa, and other Holothuriada; Ascidia and other tunicated molluscs ; various species of Starfish, Cidaris; Norwegian Lobsters; Blennys, fifteen and three spined Sticklebacks, and large numbers of living zoophytes. Several of these tanks, both in the beauty of their varied contents and the care with which they have been selected and arranged, afford a good example of what can be done by art to reproduce a portion of the richness of effect of the actual sea-bottom

On the right or seaward end of this corridor there is a Seal Tank, five seals living in it and in the Seal Pond in the garden between the entrance lodges and the portico of the Promenade Hall. On the opposite end of the corri-

* The ground slopes from the sea towards Lord Street, so that the quarium is underground on the seauard side, In my "Notes on the Geology of Liverpool," NATURE, vol. ii. p. 390 , I have described the sand dunes, \&c., of this coast. 